Article

\title{
Efficiency of Marine Bacteria and Yeasts on the Biocontrol Activity of Pythium ultimum in Ancho-Type Pepper Seedlings
}

\author{
Liliana Lara-Capistran ${ }^{1}$, Ramon Zulueta-Rodriguez ${ }^{1}$, Thelma Castellanos-Cervantes ${ }^{2}$, \\ Juan J. Reyes-Perez ${ }^{3}$ (D) , Pablo Preciado-Rangel ${ }^{4}$ and Luis G. Hernandez-Montiel ${ }^{2, * \mathbb{D}}$ \\ 1 Facultad de Ciencias Agrícolas, Campus Xalapa, Universidad Veracruzana, Xalapa 91090, Veracruz, Mexico; \\ llaracapistran@gmail.com (L.L.-C.); rzulueta36@hotmail.com (R.Z.-R.) \\ 2 Centro de Investigaciones Biológicas del Noroeste, La Paz 23096, Baja California Sur, Mexico; \\ tcastell@cibnor.mx \\ 3 Universidad Técnica Estatal de Quevedo, Quevedo EC 120501, Los Ríos, Ecuador; jjreyesp1981@gmail.com \\ 4 Tecnológico Nacional de México/ Instituto Tecnológico de Torreón, Coahuila 27170, Mexico; \\ ppreciador@yahoo.com.mx \\ * Correspondence: lhernandez@cibnor.mx; Tel.: +52-612-123-8484 (ext. 3348)
}

Received: 21 February 2020; Accepted: 10 March 2020; Published: 18 March 2020

\begin{abstract}
Ancho-type pepper (Capsicum annuum L.) is a crop susceptible to Pythium ultimum, which has already been controlled with synthetic fungicide applications; however, marine antagonist microorganisms could be an alternative source of control. The efficiency in vitro and in vivo of marine bacteria and yeasts was determined against $P$. ultimum. The inhibition of the radial growth of P. ultimum was quantified in vitro by the bacteria Stenotrophomonas rhizophila KM01 and KM02; Bacillus subtilis RBM01 and RBM02, B. amyloliquefaciens 2RLBF and 3R4CF; and Pseudomonas spp. 2R6BF and 2RE9CF, as well as the yeasts Debaryomyces hansenii 1R11AB, 1R11CB, and LL01 and Cryptococcus laurentii $2 \mathrm{R} 3 \mathrm{BF}$ and $2 \mathrm{R} 1 \mathrm{CB}$. The $\beta-1,3$-glucanase activity of the marine microorganisms was quantified in the presence of the phytopathogen. The disease index (DI), growth parameters, and colony forming units (CFU) were determined in ancho-type pepper plants inoculated with marine bacteria, yeasts, and P. ultimum. The radial zone of the phytopathogen was inhibited by $80 \%$ and $75 \%$ by $S$. rhizophila KM01 and C. laurentii 2R1CB, respectively. D. hansenii LL01 and S. rhizophila KM02 showed the highest activity of $\beta-1,3$-glucanase, with $6060 \mathrm{U} / \mathrm{mL}$ and $47 \mathrm{U} / \mathrm{mL}$, respectively. B. subtilis RBM02 protected $100 \%$ of the plants from the oomycete, and an increase was quantified in all the growth parameters and CFU. The use of these marine bacteria and yeasts are, therefore, an option for P. ultimum biocontrol in ancho-type pepper plants, thereby minimizing the application of synthetic fungicides.
\end{abstract}

Keywords: Capsicum annum L.; damping-off; marine microorganisms; oomycete

\section{Introduction}

Ancho-type pepper (Capsicum annuum L.) is an important crop worldwide, which is cultivated in greenhouses or open-fields. Damping-off disease is one of the major global factors affecting the germination of the seeds and plants of the different pepper germplasms [1,2]. Pythium damping-off has caused severe damage to the root systems of plants, with close to $70 \%$ plant mortality at the seedling stage or in the field, thus reducing the production, quality, and quantity of the pepper's harvest potential $[3,4]$.

Pre- and post-emergence damping-off disease is caused by Pythium spp. in pepper; this species is economically very important worldwide [5,6]. The rapid sporangia germination of Pythium followed 
by immediate infection makes management of this phytopathogen very difficult [7]. Several Pythium species, including P. aphanidermatum, P. irregular, and P. ultimum, are known to cause damping-off and root rot diseases in pepper [8-10]. Although synthetic fungicides have shown promising results in controlling damping-off disease, phytotoxicity and fungicide residues pose serious problems to human and animal health, as well as the environment. In this context, phytosanitary measures and the management of pepper cultivation should include the application of microorganisms as biocontrol agents to minimize the use of synthetic fungicides [11].

Bacteria and yeasts have a high capacity to control phytopathogens without causing damage to human and animal health and the environment $[12,13]$. Several mechanisms have been proposed for the biocontrol of phytopathogens by bacteria and yeasts, including competition for space and nutrients [14,15], lytic enzyme production such as $\beta-1,3$-glucanase [16,17], and induction of host resistance $[18,19]$, among others. Both microorganisms have been isolated in different terrestrial ecosystems, mainly in plants, fruits, and soils; the main bacteria used as biocontrol agents are species of Stenotrophomonas, Bacillus, and Pseudomonas, which have already been reported for the control of Fusarium proliferatum in melon [20]; Sclerotium rolfsii [21] and Rhizoctonia solani in wheat [22]; and F. solani in cassava [23], among others.

On the other hand, among the yeasts that have been used as antagonists, the species that stand out are Debaryomyces and Cryptococcus, which have been efficient in the control of Monilinia fructicola in apple [24]; Colletotrichum gloeosporioides in mango [25]; and Penicillium italicum in citrus [26], among others.

Despite the proven efficiency of isolated terrestrial bacteria and yeasts for phytopathogen control, the search for new antagonists continues; one of the ecosystems that has been rarely studied or explored is the marine environment, which may contain more efficient microorganisms for phytopathogen control than those isolated from terrestrial ecosystems [27,28]. Marine bacteria and yeasts are now being considered as new sources of biological products that can be applied in different areas, such as agriculture $[29,30]$. Until now, no information has been available on the efficiency of marine microorganisms for the control of soil diseases in horticultural plants. Therefore, the objective of this study was to assess the efficiency of marine bacteria and yeasts in the biocontrol of P. ultimum, a causal agent of damping-off disease in ancho-type pepper seedlings.

\section{Materials and Methods}

\subsection{Marine Antagonistic Microorganisms}

The bacteria and yeasts studied belonged to the collection of marine microorganisms of the Centro de Investigaciones Biológicas del Noroeste (CIBNOR). The bacteria S. rhizophila KM01 and KM02, B. subtilis RBM01 and RBM02, B. amyloliquefaciens 2RLBF and 3R4CF, and Pseudomonas spp. 2R6BF and $2 \mathrm{RE} 9 \mathrm{CF}$, as well as the yeasts $D$. hansenii $1 \mathrm{R} 11 \mathrm{AB}, 1 \mathrm{R} 11 \mathrm{CB}$, and LL01 and C. laurentii 2R3BF and 2R1CB, were assessed. The bacteria were cultured in a tryptic soy broth (TSB, Difco, BD, Franklin Lakes, NJ, USA), and the yeasts were cultured in yeast extract-peptone-dextrose (YPD, Difco, Sparks, $\mathrm{MD}, \mathrm{USA}$ ); both were incubated at $25^{\circ} \mathrm{C}$ for $24 \mathrm{~h}$. The concentration of the antagonists was adjusted to $1 \times 10^{7}$ cells $/ \mathrm{mL}$ using a digital spectrophotometer (Thermo Spectronic Genesys 20, Thermo Fisher Scientific, Inc., Waltham, MA, USA) for the bacteria, calibrated to $660 \mathrm{~nm}$ with an optical density of 0.8 ; the yeasts were adjusted using a hemocytometer.

\subsection{Pythium Ultimum}

The phytopathogen was provided by the Phytopathology Laboratory at CIBNOR. The oomycete was reactivated in a V8 medium prepared as follows: $160 \mathrm{~mL}$ of V8 vegetable juice was mixed with $3.5 \mathrm{~g}$ of $\mathrm{CaCO}_{3}$ and then clarified by filtration; subsequently, $100 \mathrm{~mL}$ of $\mathrm{V} 8$ was diluted and clarified with $1000 \mathrm{~mL}$ of sterile distilled water, adding $20 \mathrm{~g}$ of agar at $25^{\circ} \mathrm{C}$ for seven days. The concentration was adjusted to approximately $1 \times 10^{6}$ zoospores $/ \mathrm{mL}$ using a hemocytometer. 


\subsection{Pathogenicity Test}

Seeds of "Don Emilio" ancho-type pepper plants were disinfected for three minutes in 70\% ethanol; subsequently, they were left for another three minutes in sodium hypochlorite at $5 \%$ and then washed three times with sterile distilled water. They were then sown in 200-well seedbeds containing a mixture of Sunshine ${ }^{\circledR}$ substrate (Agawam, MA, USA) and organic matter $(3: 1, \mathrm{v} / \mathrm{v})$ previously sanitized with Anibac 580 liquid at a dose of $5 \mathrm{~mL} / \mathrm{L}$. One seedling was transplanted at 40 days of age after sowing into a plastic pot containing $60 \mathrm{~g}$ of substrate. At the moment of transplanting, the roots of each seedling were washed with sterile distilled water and submerged in a P. ultimum solution adjusted at $1 \times 10^{6}$ zoospores $/ \mathrm{mL}$ for $15 \mathrm{~s}$. As a control, a group of seedlings was not inoculated with the phytopathogen. Seedlings were incubated for three weeks within a controlled-environmental chamber (Conviron, Winnipeg, CAN) at $25^{\circ} \mathrm{C}$ and $95 \%$ relative humidity (RH) under a light/dark photoperiod of $12 / 12 \mathrm{~h}$. At the end of the experiment, root necrosis was quantified using the following scale [31]: $0=$ plants with unharmed roots; $1=<1 \%$ of harmed roots; $2=1 \%-3 \%$ harmed roots; $3=4 \%-5 \%$ harmed roots; $4=6 \%-10 \%$ harmed roots; and $5=>10 \%$ harmed roots.

The disease index (DI) was calculated with the following formula [32]: DI (\%) $=\Sigma[(\mathrm{Ri} \times \mathrm{Ni}) /(\mathrm{Rt}$ $\times \mathrm{Nt})] \times 100$, where $\mathrm{Ri}$ is the number of plants in the category, $\mathrm{Ni}$ is the category degree, $\mathrm{Rt}$ is the infected plant with the highest scale, and $\mathrm{Nt}$ is the total number of plants assessed. The oomycetes of the infected plants were reisolated in the V8 medium to confirm the Koch postulates. Thirty seedlings were used per treatment, and the experiment was repeated twice.

\subsection{Antagonistic Test}

Marine microorganisms were evaluated for their antagonistic activity against P. ultimum via a dual culture assay. Each marine bacterium and yeast was streaked approximately $2 \mathrm{~cm}$ from the edge of a Petri plate containing potato dextrose agar (PDA), and a $5 \mathrm{~mm}$ diameter agar plug of a seven-day-old culture of the phytopathogen was transferred to the center of a PDA plate and incubated at $25^{\circ} \mathrm{C}$ for 10 days. A group of Petri plates was inoculated with the phytopathogen and the fungicide Captan at $2 \mathrm{~g} / \mathrm{kg}$. The control consisted of a Petri plate inoculated with a $5 \mathrm{~mm}$ diameter agar plug of the oomycete without marine microorganisms. The radial growth of the phytopathogen was measured in $\mathrm{mm}$, and 10 replicates were used per treatment. The experiment was repeated twice.

\subsection{Detection of Lytic Activity}

\subsubsection{Phytopathogen Cells and Culture of Marine Microorganisms}

Pythium ultimum was cultured in a V8 medium (without agar) at $25^{\circ} \mathrm{C}$ for 10 days. Subsequently, the phytopathogen was collected using sterile gauze and macerated in liquid nitrogen. The marine bacteria and yeasts were cultivated in a mineral salt medium (MSM) supplemented with $1 \mathrm{mg} / \mathrm{mL}$ phytopathogen cells and incubated at $25^{\circ} \mathrm{C}$ for 15 days on a rotary shaker at $100 \mathrm{rpm}$. The supernatant was collected at 12 and $24 \mathrm{~h}$ to determine lytic activity. Ten replicates were used per treatment, and the experiment was repeated twice.

\subsection{2. $\beta$-1,3-glucanase Activity}

$\beta-1,3-G l u c a n a s e$ activity was detected using laminarin, as indicated by Hernandez-Montiel et al. [30], in triplicate for each treatment; this step was performed twice. Briefly, the kit used for measuring glucose release was the Randox Glucose (GOD-PAP) method at pH $5.0\left(37^{\circ} \mathrm{C}\right)$. One unit (U) of $\beta-1,3$-glucanase was defined as the $\mu \mathrm{mol}$ of reducing sugar released $/ \mathrm{mg}$ of protein per min at $37^{\circ} \mathrm{C}$ and $\mathrm{pH}$ 5.0. The total protein content of the enzyme(s) solution was quantified by the method described by Lowry et al. [33] using bovine serum albumin as a standard. 


\subsection{Inoculation of Ancho-Type Pepper Plants with Marine Bacteria and Yeasts}

The best marine antagonistic strains of the bacteria (KM01, KM02, RBM01, and RBM02) and yeasts (2R1CB, LL01, 1R11CB, and 2R3BF) were selected. The forty-day-old seedlings were deposited in plastic pot containing $60 \mathrm{~g}$ of a mixture of Sunshine ${ }^{\circledR}$ substrate (Agawam, MA, USA) and organic matter $(3: 1, \mathrm{v} / \mathrm{v})$, which was previously sanitized with Anibac 580 liquid at a dose of $5 \mathrm{~mL} / \mathrm{L}$. At the moment of transplanting, the root of each seedling was washed with distilled sterile water and submerged in a P. ultimum solution previously adjusted $\left(1 \times 10^{6}\right.$ zoospores $\left./ \mathrm{mL}\right)$ for $15 \mathrm{~s}$. Subsequently, each seedling was inoculated with $1 \mathrm{~mL}$ of each suspension of a bacterium or yeast, which was previously adjusted $\left(1 \times 10^{7}\right.$ cells $\left./ \mathrm{mL}\right)$. One seedling batch was inoculated only with the phytopathogen, and the other with the oomycete and fungicide Captan $(2 \mathrm{~g} / \mathrm{kg})$. The seedlings were incubated for four weeks inside a controlled-environmental chamber (Conviron, Winnipeg, CAN) at $25^{\circ} \mathrm{C}$ and $95 \% \mathrm{RH}$ under a light/dark photoperiod of 12/12 h. At the end of the experiment, the disease index [32], plant height, radicle volume, leaf area, and biomass were quantified. Thirty plants per treatment were used, and the experiment was repeated twice.

\subsection{Scanning Electron Microscopy Micrographs}

Samples of fresh root were taken from the ancho-type pepper plants inoculated with marine microorganisms and P. ultimum. The samples were fixed by immersion using a $0.1 \mathrm{M}$ phosphate buffered solution ( $\mathrm{pH} 7.0$ ) of glutaraldehide at $2.5 \%$ for $24 \mathrm{~h}$. Subsequently, they were processed according to the methodology proposed by Usall et al. [34] and observed with a scanning electron microscope $\left(\mathrm{S}-3000 \mathrm{~N}\right.$, Hitachi $\left.{ }^{\circledR}\right)$. Five replicates were performed per treatment, and the experiment was repeated twice.

\subsection{Root Colonization of Marine Microorganisms}

The colony forming units (CFU) of the bacteria and yeasts were determined for each treatment following the methodology proposed by Swanson et al. [35], sowing the dilution in triplicate on plates with tryptic soy agar ((TSA) Difco, BD, Franklin Lakes, NJ, USA) for the bacteria and with PDA (Merck, $\mathrm{DE})$ for yeasts. Ten replicates were performed per treatment, and the experiment was repeated twice.

\subsection{Statistical Analyses}

Data were processed by a one-way analysis of variance (ANOVA) and Tukey's test with a significance level of 5\%, using the STATISTICA software (version 8.0.360.0 StatSoft Inc., Tulsa, OK, USA) for Windows.

\section{Results}

\subsection{Pathogenicity of Pythium ultimum}

The ancho-type pepper plants showed a DI of $96 \% 21$ days after oomycete inoculation. All the plants with P. ultimum showed damping-off at the base; no signs of disease were observed in the plants without the phytopathogen. P. ultimum was reisolated from the necrotized root, confirming the Koch postulates.

\subsection{In Vitro Radial Growth of Pythium Ultimum}

The radial growth of P. ultimum was inhibited $80 \%$ and $76 \%$ by the S. rhizophila strains KM01 and KM02, respectively (Figure 1). In the treatment with the oomycete and Captan fungicide, the phytopathogen was inhibited by $69 \%$. 


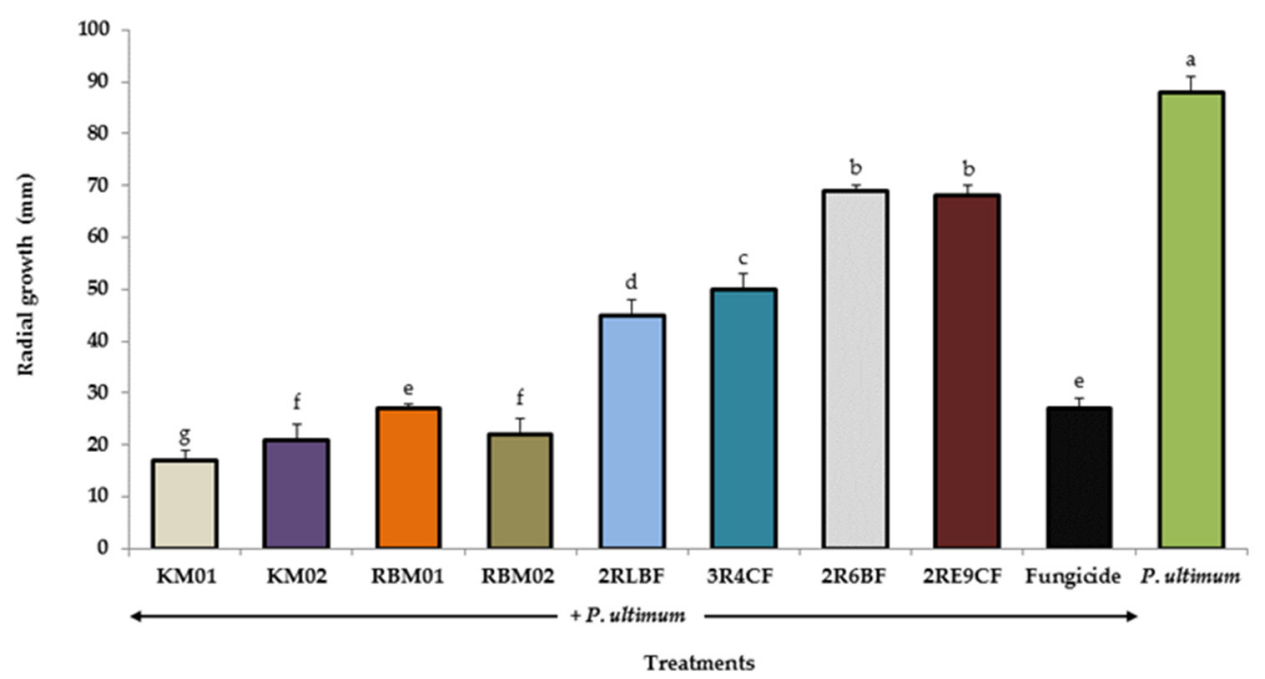

Figure 1. Effect of marine bacteria on the radial growth of Pythium ultimum. The bacteria are Stenotrophomonas rhizophila (KM01 and KM02), Bacillus subtilis (RBM01 and RBM02), B. amyloliquefaciens (2RLBF and 3R4CF), and Pseudomonas spp. (2R6BF and 2RE9CF). Data are shown as the mean \pm standard deviation (SD) $(n=100)$. Columns with different letters were significantly different according to Tukey's test $(p<0.05)$.

With respect to the marine yeasts, C. laurentii 2 R1CB inhibited $75 \%$ of the radial growth of the phytopathogen. In the treatment with the oomycete and Captan fungicide, the phytopathogen was inhibited by $66 \%$ (Figure 2).

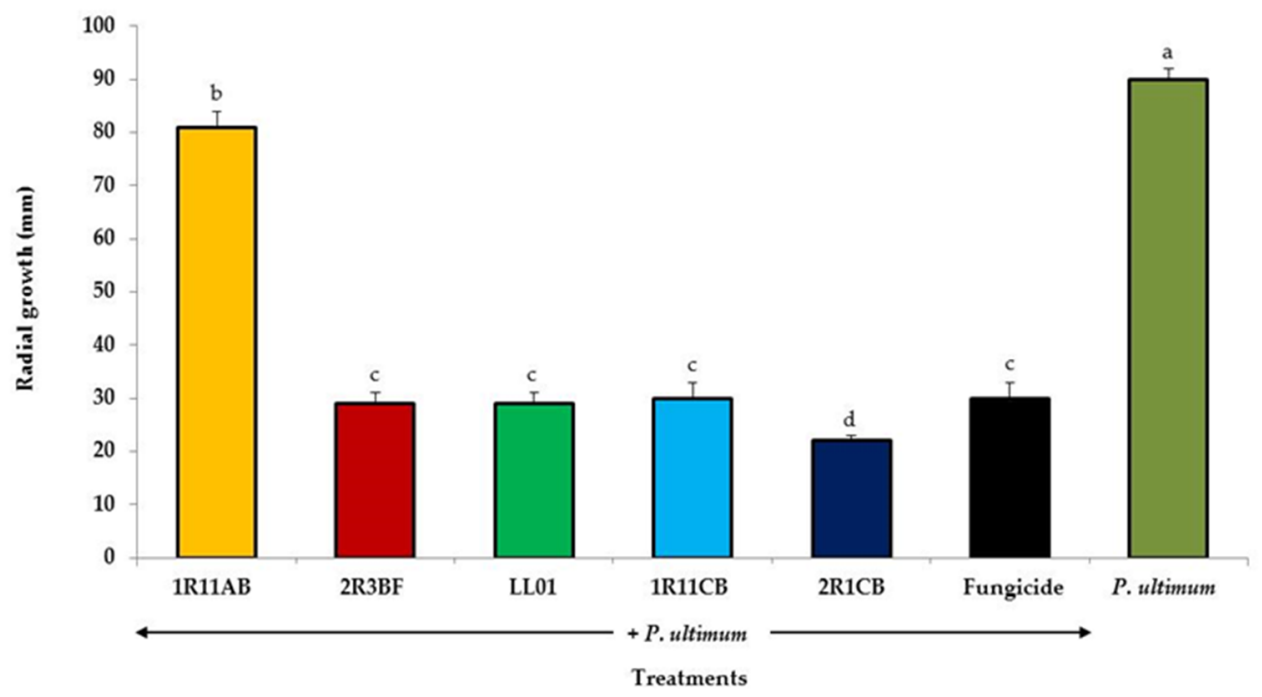

Figure 2. Effect of marine yeasts on the radial growth of Pythium ultimum. The yeasts are Debaryomyces hansenii (1R11AB, 1R11CB, and LL01) and Cryptococcus laurentii (2R3BF and 2R1CB). Data are shown as the mean \pm standard deviation (SD) $(n=100)$. Columns with different letters were significantly different according to Tukey's test $(p<0.05)$.

Based on these results, the marine bacteria S. rhizophila KM01 and KM02 and B. subtilis RBM01 and RBM02, as well as the marine yeasts D. hansenii LL01 and 1R11CB and C. laurentii 2R3BF and $2 \mathrm{R} 1 \mathrm{CB}$, were selected for inoculation in ancho-type pepper plants. 


\subsection{Lytic Activity}

The marine yeast $D$. hansenii LL01 and the marine bacterium S. rhizophila KM02 showed the highest activity of $\beta-1,3$-glucanase, with $6060 \mathrm{U} / \mathrm{mL}$ and $47 \mathrm{U} / \mathrm{mL}$, respectively (Table 1).

Table 1. Lytic activity of $\beta-1,3$-glucanase in vitro with marine bacteria and yeasts.

\begin{tabular}{|c|c|c|c|c|}
\hline \multirow{3}{*}{\multicolumn{2}{|c|}{ Microorganism }} & \multirow{3}{*}{ Strain } & \multirow{2}{*}{\multicolumn{2}{|c|}{$\begin{array}{c}\text { Lytic Activity } \\
\beta-1,3-\text { glucanase }(\mathrm{U} / \mathrm{mL})\end{array}$}} \\
\hline & & & & \\
\hline & & & $12 \mathrm{~h}$ & $24 \mathrm{~h}$ \\
\hline \multirow{8}{*}{ Bacterium } & \multirow{2}{*}{ S. rhizophila } & KM01 & $27 d^{*}$ & $41 \mathrm{e}$ \\
\hline & & KM02 & $29 \mathrm{~d}$ & $47 \mathrm{~d}$ \\
\hline & \multirow[b]{2}{*}{ B. subtilis } & RBM01 & $7 \mathrm{~g}$ & $17 \mathrm{~g}$ \\
\hline & & RBM02 & $9 \mathrm{~g}$ & $14 \mathrm{~g}$ \\
\hline & \multirow{2}{*}{ B. amyloliquefaciens } & 2RLBF & $8 \mathrm{~g}$ & $15 \mathrm{~g}$ \\
\hline & & $3 \mathrm{R} 4 \mathrm{CF}$ & $11 \mathrm{f}$ & $21 \mathrm{fg}$ \\
\hline & \multirow{2}{*}{ Pseudomonas spp. } & $2 \mathrm{R} 6 \mathrm{BF}$ & $19 \mathrm{e}$ & $40 \mathrm{e}$ \\
\hline & & 2RE9CF & $20 \mathrm{e}$ & $37 \mathrm{e}$ \\
\hline \multirow{5}{*}{ Yeast } & \multirow{3}{*}{ D. hansenii } & $1 \mathrm{R} 11 \mathrm{AB}$ & $2589 \mathrm{~b}$ & $5062 \mathrm{~b}$ \\
\hline & & 1R11CB & $2105 c$ & $3562 c$ \\
\hline & & LL01 & 3907 a & $6062 a$ \\
\hline & \multirow{2}{*}{ C. laurentii } & $2 \mathrm{R} 3 \mathrm{BF}$ & $21 \mathrm{e}$ & $40 \mathrm{e}$ \\
\hline & & 2R1CB & $19 \mathrm{e}$ & $37 \mathrm{e}$ \\
\hline
\end{tabular}

* The values are the means \pm standard deviation (SD) of 10 replicates. Different letters indicate a significant difference $(p<0.05)$ according to Tukey's test.

\subsection{Protection of Ancho-Type Pepper Plants by Marine Bacteria and Yeasts}

The marine bacterium B. subtilis RBM02 protected the ancho-type pepper plants by $100 \%$ against P. ultimum; the plants inoculated with the marine yeasts C. laurentii 2R1CB and D. hansenii LL01 showed the lowest DI (Figure 3).

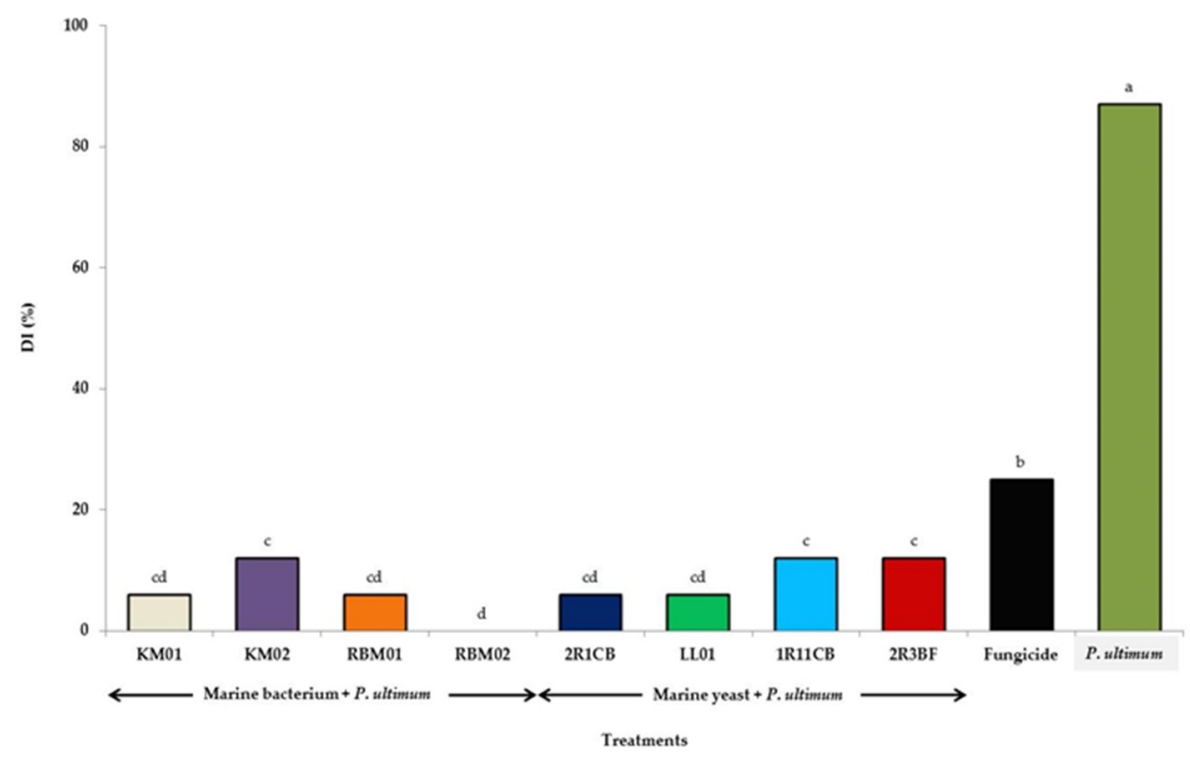

Figure 3. Disease index (DI) in the ancho-type pepper plants inoculated with Pythium ultimum and the marine microorganisms. The bacterial strains are Stenotrophomonas rhizophila (KM01 and KM02) and Bacillus subtilis (RBM01 and RBM02), and the yeasts are Cryptococcus laurentii (2R3BF and 2R1CB) and Debaryomyces hansenii (1R11CB and LL01). Data are shown as the mean \pm standard deviation (SD) $(n=30)$. Columns with different letters were significantly different according to Tukey's test $(p<0.05)$. 
The inoculated plants with the rest of the marine bacterial and yeast strains showed significantly lower DI levels, compared to the plants with the phytopathogen and Captan fungicide. Only P. ultimum produced a DI of $88 \%$. Moreover, a significant increase was observed in all the growth variables in the plants inoculated with the marine bacterium B. subtilis RBM02 and P. ultimum, compared to the treatment with fungicide Captan and the phytopathogen (Table 2).

Table 2. Growth variables in the ancho-type pepper plants inoculated with marine microorganisms and Pythium ultimum.

\begin{tabular}{|c|c|c|c|c|c|c|}
\hline Treatment & Height (cm) & $\begin{array}{l}\text { Fresh Root } \\
\text { Weight (g) }\end{array}$ & $\begin{array}{l}\text { Dry Foliage } \\
\text { Weight (g) }\end{array}$ & $\begin{array}{l}\text { Dry Weight } \\
\text { of Root (g) }\end{array}$ & $\begin{array}{l}\text { Leaf Area } \\
\left(\mathrm{cm}^{2}\right)\end{array}$ & $\begin{array}{l}\text { Radical Volume } \\
\qquad\left(\mathrm{cm}^{3}\right)\end{array}$ \\
\hline \multicolumn{7}{|l|}{ Bacterium } \\
\hline KM01 & $10.89 \mathrm{~b}$ & $3.62 \mathrm{~b}$ & $1.19 \mathrm{~b}$ & $1.03 \mathrm{~b}$ & $110.41 \mathrm{~b}$ & $28.37 \mathrm{~b}$ \\
\hline KM02 & $9.01 \mathrm{~d}$ & $1.16 \mathrm{e}$ & $0.58 \mathrm{e}$ & $0.51 \mathrm{~d}$ & $82.88 \mathrm{f}$ & $20.59 \mathrm{~d}$ \\
\hline RBM01 & $10.71 \mathrm{~b}$ & $3.56 \mathrm{~b}$ & $1.18 \mathrm{~b}$ & $1.08 \mathrm{~b}$ & 107.75 c & $28.75 \mathrm{~b}$ \\
\hline RBM02 & $12.68 \mathrm{a}$ & $4.22 \mathrm{a}$ & $1.96 \mathrm{a}$ & $1.51 \mathrm{a}$ & 120.34 a & $35.62 \mathrm{a}$ \\
\hline \multicolumn{7}{|l|}{ Yeast } \\
\hline 2R1CB & $9.98 \mathrm{c}$ & $2.86 \mathrm{c}$ & $0.82 \mathrm{c}$ & $0.72 \mathrm{c}$ & $95.33 \mathrm{~d}$ & $23.25 \mathrm{c}$ \\
\hline LL01 & $9.74 \mathrm{c}$ & $1.78 \mathrm{~d}$ & $0.75 \mathrm{~d}$ & $0.71 \mathrm{c}$ & $90.81 \mathrm{e}$ & $22.07 \mathrm{c}$ \\
\hline 1R11CB & $8.97 \mathrm{~d}$ & $1.22 \mathrm{e}$ & $0.56 \mathrm{e}$ & $0.52 \mathrm{~d}$ & $83.55 \mathrm{f}$ & $17.37 \mathrm{e}$ \\
\hline 2R3BF & $8.85 \mathrm{~d}$ & $1.15 \mathrm{e}$ & $0.56 \mathrm{e}$ & $0.49 \mathrm{~d}$ & $80.32 \mathrm{~g}$ & $17.62 \mathrm{e}$ \\
\hline Fungicide & $7.98 \mathrm{e}$ & $0.81 \mathrm{f}$ & $0.35 \mathrm{f}$ & $0.22 \mathrm{e}$ & $17.90 \mathrm{~h}$ & $6.75 \mathrm{f}$ \\
\hline P. ultimum & $5.07 \mathrm{f}$ & $0.49 \mathrm{~g}$ & $0.19 \mathrm{~g}$ & $0.11 \mathrm{f}$ & $4.77 \mathrm{i}$ & $3.11 \mathrm{~g}$ \\
\hline
\end{tabular}

* The values are the means \pm standard deviation (SD) of 30 replicates. Different letters indicate significant difference $(p<0.05)$ according to Tukey's test.

\subsection{Roots Colonized by Marine Microorganisms}

At the end of the experiment, the largest population was quantified in the plants with the marine bacterium B. subtilis RBM02 (with $740 \mathrm{CFU} / \mathrm{g}$ ) and with the marine yeasts C. laurentii 2R1CB and D. hansenii LL01 (with 430 and $421 \mathrm{CFU} / \mathrm{g}$, respectively) (Figure 4). The micrographs performed on the roots showed an abundant presence of mycelium in the plants inoculated with P. ultimum, and the bacterial and yeast cells adhered to the mycelium of the phytopathogen (Figure 5).

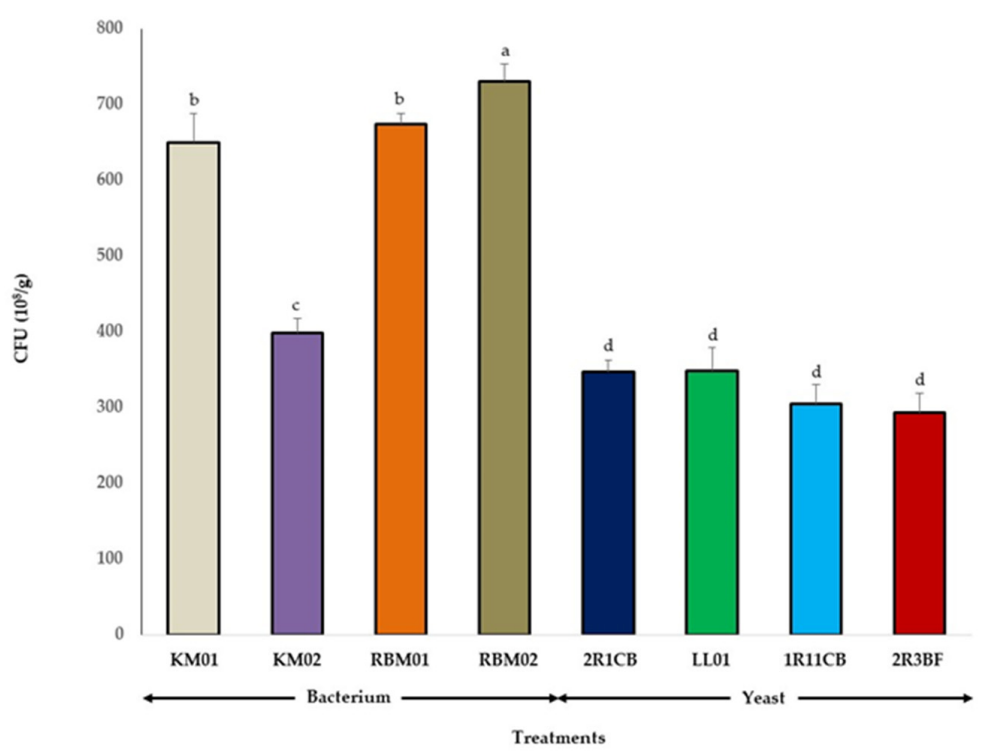

Figure 4. Colony forming units (CFU) in the roots of ancho-type pepper plants inoculated with different marine strains of bacteria and yeasts. The bacteria are Stenotrophomonas rhizophila (KM01 and KM02) and Bacillus subtilis (RBM01 and RBM02), and the yeasts are Cryptococcus laurentii (2R3BF and 2R1CB) and Debaryomyces hansenii (1R11CB and LL01). Data are shown as the mean \pm standard deviation (SD) $(n=10)$. Columns with different letters were significantly different according to Tukey's test $(p<0.05)$. 


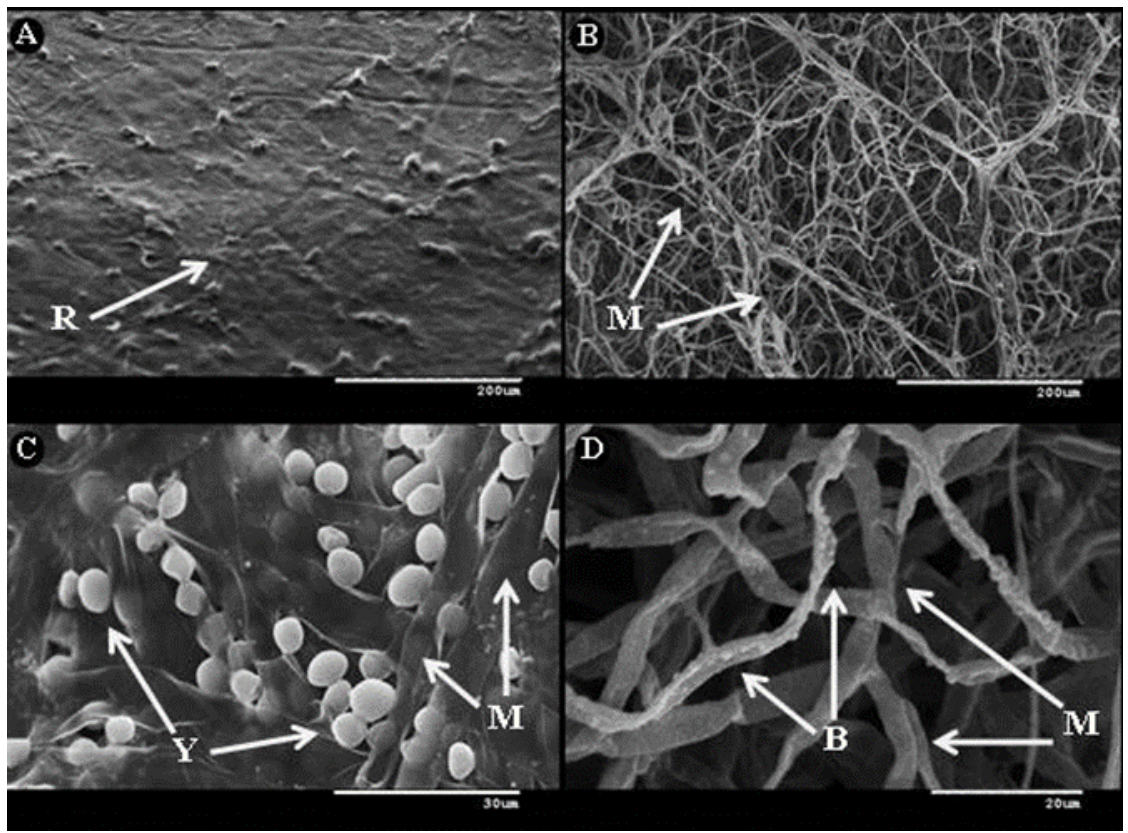

Figure 5. Micrographs from the scanning electron microscope of the inoculated roots of ancho-type pepper plants with Pythium ultimum and marine microorganisms. (A) Root (R) without microorganisms; (B) Oomycete Mycelium (M); (C) Cryptococcus laurentii (Y) 2R1CB; and (D) Bacillus subtilis (B) RBM02; both adhered to P. ultimum mycelium.

\section{Discussion}

Biological control with microorganisms has long been considered a viable alternative for controlling phytopathogens [36], among which bacteria and yeasts are the main antagonists [11,37]. In this study, different bacteria and yeasts decreased P. ultimum growth significantly in vitro; however, those that stood out most were the marine bacteria S. rhizophila (strain KM01 and KM02) and the marine yeast C. laurentii $2 \mathrm{R} 1 \mathrm{CB}$. The main antagonistic mechanisms of the bacteria and yeasts in vitro against the phytopathogens are the production of hydrolytic enzymes, such as $\beta$-1,3-glucanase [38,39], which break the links of the glucan present in the cell wall of the phytopathogen, limiting their germination and growth. This enzyme has already been reported for B. subtilis [40], S. rhizophila [30,41,42], and C. laurentii [43]. The competence for space and nutrients is another mechanism through which the bacteria and yeasts limit phytopathogens in vitro because these microorganisms have a short period of exponential growth that allows them to exhaust carbon sources in their culture medium, thereby minimizing zoospore germination and phytopathogen growth [44,45].

Marine bacteria and yeasts decreased the disease index (DI) caused by P. ultimum in ancho-type pepper plants. This protection was measured by diverse mechanisms of action, such as the production of siderophores, which are metabolites of a low molecular weight that catch the available iron in the soil, limiting growth of the phytopathogens that occupy this micro-element in different metabolic pathways, as well as in DNA [46]. The host's resistance to induction through the expression of different proteins, such as the hydrolytic proteins related to pathogenicity (protein PR), antioxidants, and the genes related to plant defense, is another mechanism exerted by bacteria and yeasts to biocontrol phytopathogens [47]. The yeast $C$. laurentii and the bacterium B. subtilis have already been reported as inductors of salicylic acid (SA) and jasmonic acid (JA) in plants. First, both genes are related to the defense of tomato against Botrytis cinerea and Alternaria alternata [48]; second, they are related to the protection of grapevine against B. cinerea [49]. On the other hand, Stenotrophomonas species have induced PR proteins in potato, thus decreasing the severity of Ralstonia solanacearum [50].

An increase was quantified in all the growth parameters of the ancho-type pepper plants inoculated with marine bacteria and yeasts. This marine microorganism's capacity to increase plant growth 
is related to different mechanisms, among which hormone production is important (of hormones such as indole ascetic acid (IAA) and gibberellins [51]), as well as phosphate solubilization [52] and atmospheric nitrogen fixation to soil [53], among others. With respect to the bacteria, several studies have reported the capacity of S. rhizophila to promote plant growth in cucumber [54], soy [55], and basil [29], as well as the different Bacillus species effects on the growth of tomato [56], wheat [57], and banana [58]. The action of yeasts is related to phytopathogen biocontrol. This study is the first report on the protection of ancho-type pepper plants against $P$. ultimum by applying marine bacteria (S. rhizophila, B. subtilis, B. amyloliquefaciens, and Pseudomonas spp.) and marine yeasts (D. hansenii and C. laurentii) (besides their roles as plant growth promoting microorganisms).

Finally, oomycete biocontrol efficiency and plant growth promoters are related to the capacity of the microorganisms to colonize and persist in plant roots and displace the host phytopathogen $[59,60]$. Therefore, it is important to select organisms that are capable of colonizing the plant rhizosphere rapidly and have prolonged persistence though time [61]. Further, in-depth studies should be performed on the mechanisms of action of marine microorganisms against $P$. ultimum to determine the minimum inhibitory concentration of each of them against the oomycete and to design agricultural management practices that limit the phytopathogens of soil under different agricultural cultivations.

\section{Conclusions}

The marine bacteria $S$. rhizophila and marine yeast $C$. laurentii showed the greatest antagonistic activity against $P$. ultimum in vitro and in vivo. The ancho-type pepper plants inoculated with the different marine bacterial and yeast strains showed the highest values in all the growth variables assessed. The disease index (DI) of the inoculated plants with P. ultimum and the different marine bacterial and yeast strains showed the lowest indexes in damage, surpassing the protective effect of the synthetic fungicide. The antagonism of marine bacteria and yeasts to phytopathogens is comparable with the biocontrol by microorganisms isolated from terrestrial environments. Therefore, marine microorganisms may have the potential to be used in plant bioprotection against phytopathogens and as plant growth promoters.

Author Contributions: Conceptualization: L.L.-C., R.Z.-R., and L.G.H.-M.; methodology: L.L.-C., P.P.-R., and L.G.H.-M.; validation: R.Z.-R. and J.J.R.-P.; formal analysis: J.J.R.-P. and T.C.-C.; investigation: L.L.-C., R.Z.-R., and L.G.H.-M.; writing-original draft preparation: L.L.-C. and T.C.-C.; writing-review and editing: R.Z.-R., P.P.-R., and L.G.H.-M.; supervision: L.L.-C. and R.Z.-R.; project administration: J.J.R.-P. and L.G.H.-M.; funding acquisition: L.L.-C. and L.G.H.-M. All authors have read and agreed to the published version of the manuscript.

Funding: This research was funded by the project grant SEP-CONACYT 181972 and the project Problemas Nacionales grant 2015-01-352 CONACYT (Consejo Nacional de Ciencia y Tecnologia).

Acknowledgments: The authors are thankful to D. Fischer for editorial support.

Conflicts of Interest: The authors declare no conflicts of interest.

\section{References}

1. Hyder, S.; Naseem, S.; Azhar, S.; Ashfaq, M.; Ali, Z.; Khalid, A.; Inam-ul-Haq, M. Disease incidence and severity of Pythium spp. and Phytophthora spp. affecting chili pepper and tomato crops in Punjab, Pakistan. Philipp. Agric. Sci. 2018, 101, 36-44.

2. Lema, A.A.; Mudansiru, A.; Alexander, B.A.; Sakinatu, M.J. Evaluation of fungal species isolated from three different varieties of pepper (Capsicum chinense, C. frutescens and C. annumm L.) in Dutsin-ma, Katsina State. Ann. Biol. Sci. 2018, 6, 13-17. [CrossRef]

3. Zagade, S.N.; Deshpande, G.D.; Gawade, D.B.; Atnoorkar, A.A.; Pawar, S.V. Biocontrol agents and fungicides for management of damping off in chilli. World J. Agric. Sci. 2012, 8, 590-597.

4. Halo, B.A.; Al-Yahyai, R.A.; Maharachchikumbura, S.S.; Al-Sadi, A.M. Talaromyces variabilis interferes with Pythium aphanidermatum growth and suppresses Pythium-induced damping-off of cucumbers and tomatoes. Sci. Rep. 2019, 9, 11255. [CrossRef] 
5. $\quad$ Lamichhane, J.R.; Dürr, C.; Schwanck, A.A.; Robin, M.H.; Sarthou, J.P.; Cellier, V.; Messéan, J.; Aubertot, J.N. Integrated management of damping-off diseases. A review. Agron. Sustain. Dev. 2017, 37, 10. [CrossRef]

6. Pandey, M.; Ahmad, S.; Khan, K.Z. Efficacy of selected plant extracts and biocontrol agents against damping-off (Pythium aphanidermatum) of chilli. Res. Environ. Life Sci. 2017, 10, 87-90.

7. Grijalba, P.E.; Ridao, A.C.; Steciow, M.; López, M.V. Relationship between Rps 1k gene and resistance to Pythium ultimum and P. irregulare in soybean. Summa Phytopathol. 2017, 43, 94-97. [CrossRef]

8. Tekale, A.G.; Guldekar, D.D.; Kendre, V.P.; Deshmukh, A.P.; Potdukhe, S.R. Efficacy of fungicides and bioagents against damping off in chilli caused by Pythium aphanidermatum. Int. J. Curr. Microbiol. App. Sci. 2019, 8, 637-648. [CrossRef]

9. Muthu, K.A. Occurrence and distribution of indigenous isolates of Pythium species in northern India. Adv. Plants Agric. Res. 2016, 4, 319-327.

10. Pandey, M.; Ahmad, S.; John, S.A.; Khan, K.Z. Antifungal potential of native Trichoderma isolates against Pythium aphanidermatum causing chilli damping-off. Ann. Plant Prot. Sci. 2019, 27, 102-106. [CrossRef]

11. Liu, K.; McInroy, J.A.; Hu, C.H.; Kloepper, J.W. Mixtures of Plant-Growth-Promoting rhizobacteria enhance biological control of multiple plant diseases and plant-growth promotion in the presence of pathogens. Plant Dis. 2018, 102, 67-72. [CrossRef] [PubMed]

12. Selim, H.M.; Gomaa, N.M.; Essa, A.M. Application of endophytic bacteria for the biocontrol of Rhizoctonia solani (Cantharellales: Ceratobasidiaceae) damping-off disease in cotton seedlings. Biocontrol Sci. Technol. 2017, 27, 81-95. [CrossRef]

13. Le, C.N.; Hoang, T.K.; Thai, T.H.; Tran, T.L.; Phan, T.P.N.; Raaijmakers, J.M. Isolation, characterization and comparative analysis of plant-associated bacteria for suppression of soil-borne diseases of field-grown groundnut in Vietnam. Biol. Control 2018, 121, 256-262. [CrossRef]

14. Haidar, R.; Fermaud, M.; Calvo-Garrido, C.; Roudet, J.; Deschamps, A. Modes of action for biological control of Botrytis cinerea by antagonistic bacteria. Phytopathol. Mediterr. 2016, 55, 301-322.

15. Lin, M.; Zhang, Y.; Sun, C.; Huang, Y.; Zhang, J.; Zheng, X.; Yu, T. Characterization and overexpression of RHO1 from Cryptococcus laurentii ZJU10 activates CWI signaling pathway on enhancing the inhibition of blue mold on pears. Int. J. Food Microbiol. 2018, 278, 1-10. [CrossRef]

16. Bodhankar, S.; Grover, M.; Hemanth, S.; Reddy, G.; Rasul, S.; Yadav, S.K.; Desai, S.; Mallappa, M.; Mandapaka, M.; Srinivasarao, C. Maize seed endophytic bacteria: Dominance of antagonistic, lytic enzyme-producing Bacillus spp. 3 Biotech 2017, 7, 232. [CrossRef]

17. Zhang, S.B.; Zhang, W.J.; Zhai, H.C.; Lv, Y.Y.; Cai, J.P.; Jia, F.; Wang, J.S.; Hu, Y.S. Expression of a wheat $\beta$-1,3-glucanase in Pichia pastoris and its inhibitory effect on fungi commonly associated with wheat kernel. Protein Expr. Purif. 2019, 154, 134-139. [CrossRef]

18. Gond, S.K.; Bergen, M.S.; Torres, M.S.; White, J.F., Jr. Endophytic Bacillus spp. produce antifungal lipopeptides and induce host defence gene expression in maize. Microbiol. Res. 2015, 172, 79-87. [CrossRef]

19. Sun, C.; Fu, D.; Lu, H.; Zhang, J.; Zheng, X.; Yu, T. Autoclaved yeast enhances the resistance against Penicillium expansum in postharvest pear fruit and its possible mechanisms of action. Biol. Control 2018, 119, 51-58. [CrossRef]

20. Rivas-Garcia, T.; Murillo-Amador, B.; Nieto-Garibay, A.; Chiquito-Contreras, R.; Rincon-Enriquez, G.; Hernandez-Montiel, L.G. Effect of ulvan on the biocontrol activity of Debaryomyces hansenii and Stenotrophomonas rhizophila against fruit rot of Cucumis melo L. Agronomy 2018, 8, 273. [CrossRef]

21. Ünal, F.; Aşkın, A.; Koca, E.; Yıldırır, M.; Bingöl, M.Ü. Mycelial compatibility groups, pathogenic diversity and biological control of Sclerotium rolfsii on turfgrass. Egypt. J. Biol. Pest Control 2019, 29, 44. [CrossRef]

22. Jaaffar, A.K.M.; Parejko, J.A.; Paulitz, T.C.; Weller, D.M.; Thomashow, L.S. Sensitivity of Rhizoctonia isolates to phenazine-1-carboxylic acid and biological control by phenazine-producing Pseudomonas spp. Phytopathology 2017, 107, 692-703. [CrossRef]

23. Freitas, M.A.; Medeiros, F.H.; Melo, I.S.; Pereira, P.F.; Peñaflor, M.F.G.; Bento, J.M.; Paré, P.W. Stem inoculation with bacterial strains Bacillus amyloliquefaciens (GB03) and Microbacterium imperiale (MAIIF2a) mitigates fusarium root rot in cassava. Phytoparasitica 2019, 47, 135-142. [CrossRef]

24. Czarnecka, M.; Żarowska, B.; Połomska, X.; Restuccia, C.; Cirvilleri, G. Role of biocontrol yeasts Debaryomyces hansenii and Wickerhamomyces anomalus in plants defence mechanisms against Monilinia fructicola in apple fruits. Food Microbiol. 2019, 83, 1-8. [CrossRef] 
25. Zhou, Y.; Li, W.; Zeng, J.; Shao, Y. Mechanisms of action of the yeast Debaryomyces nepalensis for control of the pathogen Colletotrichum gloeosporioides in mango fruit. Biol. Control 2018, 123, 111-119. [CrossRef]

26. Li, J.; Li, H.; Ji, S.; Chen, T.; Tian, S.; Qin, G. Enhancement of biocontrol efficacy of Cryptococcus laurentii by cinnamic acid against Penicillium italicum in citrus fruit. Postharvest Biol. Technol. 2019, 149, 42-49. [CrossRef]

27. Hernandez-Montiel, L.G.; Zulueta-Rodriguez, R.; Angulo, C.; Rueda-Puente, E.O.; Quiñonez-Aguilar, E.E.; Galicia, R. Marine yeasts and bacteria as biological control agents against anthracnose on mango. J. Phytopathol. 2017, 165, 833-840. [CrossRef]

28. Dionisi, H.M.; Lozada, M.; Olivera, N.L. Bioprospection of marine microorganisms: Biotechnological applications and methods. Rev. Argent. Microbiol. 2012, 44, 49-60.

29. Chiquito-Contreras, R.G.; Solís-Palacios, R.; Reyes-Pérez, J.J.; Murillo-Amador, B.; Alejandre-Rosas, J.; Hernández-Montiel, L.G. Promoción del crecimiento de plantas de albahaca utilizando hongos micorrízicos arbusculares y una bacteria marina. Acta Universitaria 2018, 28, 68-76. [CrossRef]

30. Hernandez-Montiel, L.G.; Gutierrez-Perez, E.; Murillo-Amador, B.; Vero, S.; Chiquito-Contreras, R.G.; Rincon-Enriquez, G. Mechanisms employed by Debaryomyces hansenii in biological control of anthracnose disease on papaya fruit. Postharvest Biol. Technol. 2018, 139, 31-37. [CrossRef]

31. St-Arnaud, M.; Hamel, C.; Caron, M.; Fortin, J.A. Inhibition of Pythium ultimum in roots and growth substrate of mycorrhizal Tagetes patula colonized with Glomus intraradices. Can. J. Plant Pathol. 1994, 16, 187-194. [CrossRef]

32. Akköpru, A.; Demir, S. Biological control of Fusarium wilt in tomato caused by Fusarium oxysporum f.sp. lycopersici by AMF Glomus intraradices and some rhizobacteria. J. Plant Physiol. 2005, 153, 544-550.

33. Lowry, O.H.; Rosebrough, N.J.; Farr, A.L.; Randall, R.J. Protein measurement with the Folin phenol reagent. J. Biol. Chem. 1951, 193, 265-275.

34. Usall, J.; Teixido, N.; Torres, R.; Ochoa, X.; Viñas, I. Pilot test of Candida sake (CPA) applications to control postharvest blue mold on apple fruit. Postharvest Biol. Technol. 2001, 21, 147-156. [CrossRef]

35. Swanson, K.M.; Petran, R.L.; Hanlin, J.H. Culture methods for enumeration of microorganisms. In Compendium of Methods for the Microbiological Examination of Foods; Downs, F.P., Ito, K., Eds.; APHA: Washington, DC, USA, 2001; pp. 53-67.

36. Koch, E.; Becker, J.O.; Berg, G.; Hauschild, R.; Jehle, J.; Köhl, J.; Smalla, K. Biocontrol of plant diseases is not an unsafe technology! J. Plant Dis. Protect. 2018, 125, 121-125. [CrossRef]

37. Pretscher, J.; Fischkal, T.; Branscheidt, S.; Jäger, L.; Kahl, S.; Schlander, M.; Thinesm, E.; Claus, H. Yeasts from different habitats and their potential as biocontrol agents. Fermentation 2018, 4, 31. [CrossRef]

38. Reddy, M.R.; Shivaprakash, M.K.; Adithya, S. In Vitro evaluation of bacterial endophytes for biocontrol of Pythium aphanidermatum and plant growth promotion in Setaria italica L. grown in seedling trays. Curr. J. Appl. Sci. Technol. 2019, 38, 1-14. [CrossRef]

39. Zhao, L.; Wang, Y.; Wang, Y.; Li, B.; Gu, X.; Zhang, X.; Boateng, N.A.S.; Zhang, H. Effect of $\beta$-glucan on the biocontrol efficacy of Cryptococcus podzolicus against postharvest decay of pears and the possible mechanisms involved. Postharvest Biol. Technol. 2020, 160, 111057. [CrossRef]

40. Dewi, R.T.K.; Mubarik, N.R.; Suhartono, M.T. Medium optimization of $\beta$-glucanase production by Bacillus subtilis SAHA 32.6 used as biological control of oil palm pathogen. Emir. J. Food Agric. 2016, 28, 116-125. [CrossRef]

41. Bibi, F.; Yasir, M.; Song, G.C.; Lee, S.Y.; Chung, Y.R. Diversity and characterization of endophytic bacteria associated with tidal flat plants and their antagonistic effects on oomycetous plant pathogens. Plant Pathol. J. 2012, 28, 20-31. [CrossRef]

42. Reyes-Perez, J.J.; Hernandez-Montiel, L.G.; Vero, S.; Noa-Carrazana, J.C.; Quiñones-Aguilar, E.E.; Rincón-Enríquez, G. Postharvest biocontrol of Colletotrichum gloeosporioides on mango using the marine bacterium Stenotrophomonas rhizophila and its possible mechanisms of action. J. Food Sci. Technol. 2019, 56, 4992-4999. [CrossRef]

43. Zeng, L.; Yu, C.; Fu, D.; Lu, H.; Zhu, R.; Lu, L.; Zheng, X.; Yu, T. Improvement in the effectiveness of Cryptococcus laurentii to control postharvest blue mold of pear by its culture in $\beta$-glucan amended nutrient broth. Postharvest Biol. Technol. 2015, 104, 26-32. [CrossRef]

44. Schreiter, S.; Sandmann, M.; Smalla, K.; Grosch, R. Soil type dependent rhizosphere competence and biocontrol of two bacterial inoculant strains and their effects on the rhizosphere microbial community of field-grown lettuce. PLoS ONE 2014, 9, e103726. [CrossRef] 
45. Tan, C.; Wang, L.; Xue, Y.; Lin, S.; Yu, G.; Yang, S. Purification and molecular characterization of a Metschnikowia saccharicola killer toxin lethal to a crab pathogenic yeast. FEMS Microbiol. Lett. 2018, 365, fny038. [CrossRef]

46. Pi, H.; Helmann, J.D. Sequential induction of Fur-regulated genes in response to iron limitation in Bacillus subtilis. Proc. Natl. Acad. Sci. USA 2017, 114, 12785-12790. [CrossRef]

47. Romanazzi, G.; Sanzani, S.M.; Bi, Y.; Tian, S.; Martínez, P.G.; Alkan, N. Induced resistance to control postharvest decay of fruit and vegetables. Postharvest Biol. Technol. 2016, 122, 82-94. [CrossRef]

48. Lai, J.; Cao, X.; Yu, T.; Wang, Q.; Zhang, Y.; Zheng, X.; Lu, H. Effect of Cryptococcus laurentii on inducing disease resistance in cherry tomato fruit with focus on the expression of defense-related genes. Food Chem. 2018, 254, 208-216. [CrossRef]

49. Farace, G.; Fernandez, O.; Jacquens, L.; Coutte, F.; Krier, F.; Jacques, P.; Clément, C.; Ait Barka, E.; Jacquard, C.; Dore, S. Cyclic lipopeptides from Bacillus subtilis activate distinct patterns of defence responses in grapevine. Mol. Plant Pathol. 2015, 16, 177-187. [CrossRef]

50. Elhalag, K.M.; Messiha, N.A.S.; Emara, H.M.; Abdallah, S.A. Evaluation of antibacterial activity of Stenotrophomonas maltophilia against Ralstonia solanacearum under different application conditions. J. Appl. Microbiol. 2016, 120, 1629-1645. [CrossRef]

51. Tabatabaei, S.; Ehsanzadeh, P.; Etesami, H.; Alikhani, H.A.; Glick, B.R. Indole-3-acetic acid (IAA) producing Pseudomonas isolates inhibit seed germination and $\alpha$-amylase activity in durum wheat (Triticum turgidum L.). Span. J. Agric. Res. 2016, 14, e0802. [CrossRef]

52. Sharma, S.; Kumar, V.; Tripathi, R.B. Isolation of phosphate solubilizing microorganism (PSMs) from soil. J. Microbiol. Biotechnol. Res. 2017, 1, 90-95.

53. Pham, V.T.; Rediers, H.; Ghequire, M.G.; Nguyen, H.H.; De Mot, R.; Vanderleyden, J.; Spaepen, S. The plant growth-promoting effect of the nitrogen-fixing endophyte Pseudomonas stutzeri A15. Arch. Microbiol. 2017, 199, 513-517. [CrossRef]

54. Egamberdieva, D.; Kucharova, Z.; Davranov, K.; Berg, G.; Makarova, N.; Azarova, T.; Chebotar, V.; Tikhonovich, I.; Kamilova, F.; Validov, S.Z.; et al. Bacteria able to control foot and root rot and to promote growth of cucumber in salinated soils. Biol. Fertil. Soils 2011, 47, 197-205. [CrossRef]

55. Egamberdieva, D.; Jabborova, D.; Berg, G. Synergistic interactions between Bradyrhizobium japonicum and the endophyte Stenotrophomonas rhizophila and their effects on growth, and nodulation of soybean under salt stress. Plant Soil 2016, 405, 35-45. [CrossRef]

56. Tahir, H.A.; Gu, Q.; Wu, H.; Raza, W.; Hanif, A.; Wu, L.; Colman, M.V.; Gao, X. Plant growth promotion by volatile organic compounds produced by Bacillus subtilis SYST2. Front. Microbiol. 2017, 8, 171. [CrossRef]

57. Verma, V.; Ravindran, P.; Kumar, P.P. Plant hormone-mediated regulation of stress responses. BMC Plant Biol. 2016, 16, 86. [CrossRef]

58. Gamez, R.; Cardinale, M.; Montes, M.; Ramirez, S.; Schnell, S.; Rodriguez, F. Screening, plant growth promotion and root colonization pattern of two rhizobacteria (Pseudomonas fluorescens Ps006 and Bacillus amyloliquefaciens Bs006) on banana cv. Williams (Musa acuminata Colla). Microbiol. Res. 2019, 220, 12-20. [CrossRef]

59. Lee, G.; Lee, S.H.; Kim, K.M.; Ryu, C.M. Foliar application of the leaf-colonizing yeast Pseudozyma churashimaensis elicits systemic defense of pepper against bacterial and viral pathogens. Sci. Rep. 2017, 7, 39432. [CrossRef]

60. Joubert, P.M.; Doty, S.L. Endophytic yeasts: Biology, ecology and applications. In Endophytes of Forest Trees; Pirttilä, A., Frank, A., Eds.; Springer: Cham, Switzerland, 2018; pp. 3-14.

61. Kandel, S.L.; Joubert, P.M.; Doty, S.L. Bacterial endophyte colonization and distribution within plants. Microorganisms 2017, 5, 77. [CrossRef]

(C) 2020 by the authors. Licensee MDPI, Basel, Switzerland. This article is an open access article distributed under the terms and conditions of the Creative Commons Attribution (CC BY) license (http://creativecommons.org/licenses/by/4.0/). 